\title{
A Critical Discourse Analysis of the Reconstructed National Identities in Selected Scottish and British Political Speeches with Reference to the Scottish Referendum
}

\author{
* Sarah Ali Hussein \\ MA Candidate at Department of English, \\ College of Education for Humanities, \\ E-Mail sarah040ali@gmail.com
}

Tel. 07805330270

\author{
Hashim Aliwy Mohammed Alhusseini (Ph.D) \\ Department of English, College of Education for \\ Humanities, University of Wasit, Iraq \\ E-Mail: alhili.usm@gmail.com \\ 07802621440
}

University of Wasit, Iraq

\begin{abstract}
This paper presents a critical discourse analysis of the discursive construction of national identity in selected political discourses. The nationalist narratives affect the ways people view problems that are related to them as a group, i.e. related to their ethnicity, nation, and country. Because of the effective role of the national narratives in directing people's decisions, the study aims to investigate the ways in which national identities are maintained or reproduced in political discourse to reach political purposes. Thus, the researchers use a qualitative thematic analysis based on three levels to investigate the construction of the national identity in discourse. To achieve this aim, the study analyses two political speeches in which one of them is presented by the First Minster of Scotland Alex Salmond and the second one is given by the Prime Minister of the UK David Cameron. Both speeches are presented a day after the Scottish independence referendum. The researchers employ Wodak, de Cillia, Reisigl and Liebhart's (2009) theory of the discursive construction of national identity to examine the strategies that are used by those opposing sides to maintain or reproduce a specific national identification. The study arrives at identifying certain strategies used to express the opposing views of both politicians to construct, maintain or destroy national identities.
\end{abstract}

Keywords: CDA, National identity, Scotland, Britain, The Scottish referendum

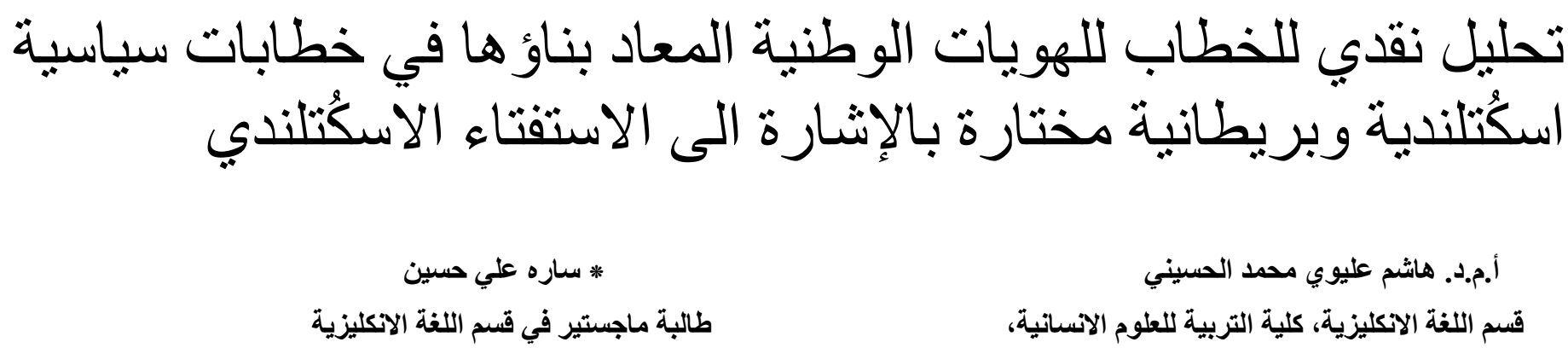


تعرضُ هذه الورقة البحثية تحليل نقدي للبناء الخطابي للهوية الوطنية في خطابات سياسية مختارة. تؤثر المرويات والخطابات الوطنية بالطرق التي يستعرض بها الناس المسائل المرتبطة بهم كمجموعة، أي، مرتبطة بقومياتهم، امَتهم، وبلدانهم. نظر الدور المرويات الوطنية المؤثر في توجيه قرار ات الاشخاص، تهدف الدر اسة إلى التحقق من وسائل المحافظة على الهوية الوطنية أو إعادة بنائها في الخطاب السياسي لتحقيق غايات سياسية. وبالتالي، يستخدم الباحثان تحليلاً نوعي مواضيعي مبنياً على ثلاث مستويات لاستقصاء بناء الهوية الوطنية في الخطابات. لتحقيق هذا الهدف، تحلل الدراسة خطابين سياسيين احدهما للوزير الاول في اسكُنلندالAlex Salmond والآخر لرئيس وزراء المملكة Wodak, de تمتحدة David Cameron تقديم كِلا الخطابين في اليوم التالي للاستفتاء الاسكُتلندي للاستقلال. وظّفت الباحثان نظرية Cillia, Reisigl and Liebhart's (2009) المتعارضان للمحافظة على هويات وطنية معينة أو إعادة بنائها. تتوصل الدراسة الى تحديد الاستراتيجيات المستخدمة للتعبير عن وجهات النظر المتعارضة لكِلا السياسيَيّن لبناء الهويات الوطنية، او الحفاظ عليها او تدمير ها. الكلمات المفتاحية: التحليل النقدي للخطاب، الهوية الوطنية، اسكُتلندا، بريطانيا، الاستقتاء الاسكُتلندي

\section{Introduction}

The constant change in this world leads to a constant struggle between the different political forces. Politics is regarded as one of the social fields that is directly linked with ideology. Through discourse, political ideologies are presented to the world. Discourse as a means is used to make ideologies concrete, specific and influential (van Dijk, 2005, p, 731-34). Reisigl and Wodak (2017, p. 88) describe ideology as a specific view of the world that consists of mental representations, opinions, attitudes, and evaluations that are common between the members of a particular group.

According to Özkirimli's (2010) view, discourses are described as "statements that are enacted within a social context and determined by that social context" (p. 208), so they cannot be dealt with as merely language. Thus, by presenting issues like nationalism as discourse, this provides a "particular way of seeing and interpreting the world, a frame of reference that helps us make sense of and structure the reality that surrounds us" (Özkirimli, 2010, p. 206). Jaffrelot (2017, p. 159) gives an account to the ideological dimension of nationalism and defines it as the effective loyalty of a group of people to a nation whether it was a state or to a nation with a tendency for separatism or independence. The most important factor for a group is to have a common political identification (a state- a nation) or an explicit national project towards a particular national tendency. Consequently, Jaffrelot (2017) sees nationalism as an ideology, in spite of the fact that many theorists of nationalism have reduced the influence of ideology in the formation of this national loyalty. Van den Berghe (1995, p. 360) defines a nation as a group of people that unite in order to create and recreate a collectivity of "pre-existing or invented" historical, geographical, cultural, and sociopolitical features to distinguish them from other groups.

As Halbwachs (1985) puts it, the collective memory that is shared by a particular group is described as comprising the national identity of that 
group. This study investigates the historical, social and linguistic aspects of national identity in political discourse with specific reference to the Scottish independence referendum. A systematic analysis is used to explain the reproduction of national identities in relation to different ethnic groups. Politicians, such as the First Minister of Scotland Alex Salmond and the Prime Minister (henceforth PM) of the United Kingdom David Cameron, have employed narratives of national identities either as a discursive strategy that promotes sameness or difference according to Wodak, de Cillia, Reisigl and Liebhart's (2009) view of the discursive construction of national identity.

\section{Literature Review}

This section provides an introduction about studies related to national identity and discourse, an overview about the Scots and Scotland, and a brief overview about Critical Discourse Analysis (henceforth CDA) and the different theories related to it.

\subsection{A Review of Related Studies}

There is a number of research studies that have dealt with the discursive construction of national identities in different settings and different periods of time. For instance, Wodak et al. (2009) presented a new way of analysis within the Discourse Historical Approach (henceforth DHA) by studying the discursive construction of the Austrian national identity in multiple contexts. Another study is conducted by Sheyholislami (2011) in which he discusses the ways in which Kurdish national identity has been constructed through the use of satellite television and the internet using an interdisciplinary approach of CDA. Finally, Skenderi (2014) presents an analysis using CDA of the construction of Balkan identity in political speeches and how the European agenda affected the content of those speeches.

\subsection{The Scots and Scotland: An Overview}

The history of Scotland as an independent country goes back to the first millennium. After the death of the king of Alba, this piece of land was invaded by King Edward I of England and made it a part of his empire. The period of Wars of Independence (12961328) started to expose the rejection of the people of Scotland of the English dominance. After centuries, the Scots continued their demands for independence from their closet neighbours. In 1960s, the Scottish National Party (henceforth SNP) came out to the light as a prominent force in Scotland that called for independence (Ichijo, 2004, p. 8-11).

According to Brand (1978, p. 233), the anti-Union sentiment has grown by the passage of time as the Scottish nationalism has been gaining representatives, especially the SNP leader Salmond who explicitly presented his request for full independence for Scotland. Esman (1977) explains that economic grievances may represent one reason behind the rise of support for the goals of the Nationalists. This factor is employed by the Nationalist parties to sell the idea of independence to the public (Glen, 2015, p. 7).

The Scots accepted the British identity and maintained their Scottish cultural heritage as a distinct part of their identity. Over time, different waves of Scottish nationalism appeared and spread demanding independence from the old Union. The SNP launched a campaign in May 2012 to promote and support the independence referendum of Scotland. This campaign was led by the Scottish First Minister Alex Salmond as the leader of the SNP and the representative of the Yes Scotland campaign. After signing the agreement of the terms of the referendum, its date was set on 18 September 2014. The Scottish referendum in 2014 recorded the 
highest point of supporters in the modern history supported by the Yes Campaign (Glen, 2015, p. 17). The question that was presented to the people to vote on was "Should Scotland be an independent country?", with a required answer of Yes/ No. On the opposing side, there was the Better Together Campaign which supported the Union and was supported by the Prime Minister of the UK, David Cameron. The official results of this referendum were $44.7 \%$ of Yes votes, and $53.3 \%$ of No votes (BBC News, 2014).

In this study, the Yes Scotland campaign data consists of one speech presented by the former First Minister of Scotland and the leader of SNP Alex Salmond. The speech was presented on 19 September (See appendix 1), 2014. On the other hand, the Better Together Campaign data involves also one speech given by the former Prime Minister David Cameron as a supporter of the Union which was presented on 19 September 2014 (See appendix 2).

\subsection{Critical Discourse Analysis}

The term "discourse" is regarded as an umbrella that covers a wide area in linguistics and other disciplines such as anthropology, philosophy, and psychology. In linguistics, many studies show that the sentence level cannot be regarded as the last border in language. Discourse is used to cover an area that extends beyond the sentence level. Since discourse can be found in different fields, there are various views about discourse and discourse analysis (Tannen, Schiffrin, \& Hamilton, 2001, p. 1). Discourse research studies the enactment, reproduction, and legitimation of inequality and power abuse by investigating verbal utterance whether a talk or text in both social and political contexts (van Dijk, 2015, p. 466).
Rash (2012, p. 1) explains that the specific aim behind developing CDA is to interpret political discourse since the main interest of the critical discourse analysts is how to investigate the ways in which discourse reflects and maintains the structure of power in society. According to Meyer (2001, p. 29), CDA is not a fixed or an unchanging approach; it is a problem oriented approach that includes a number of approaches that suit the problem under investigation. Some of the theories that are relevant to CDA and to this study are Critical Linguistics (henceforth CL), Fairclough's (1995) Sociocultural Approach, van Dijk's (2005) Socio-Cognitive Approach, and the Discourse-Historical Approach (henceforth DHA), specifically Wodak et al.'s the discursive construction of national identity approach (2009).

Critical Linguistics is one of the most influential approaches within linguistics. It is based on the work of Fowler, Hodge, Kress, \& Trew (1979). Fowler (1991, p. 5) explains that CL studies "the relations between signs, meanings and social and historical conditions which govern the semiotic structure of discourse, using a particular kind of linguistic analysis". This approach employs Halliday's (1984) Systematic-Functional Grammar in analysing discourse.

Fairclough (1995, p. 56) focuses on the ways in which discourse represents the social conflict according to the Marxist tradition. He concentrates his attention on ideas like dominance, difference, and resistance. He also introduces discourse as a product of constructing different aspects of the social structure. This constructive role is reflected in three ways which are constructing the social identity, social relations among people, and constructing systems of beliefs within a particular group.

According to van Dijk (1998, p. 69), one of the major aims of CDA is to use text analysis to uncover 
the sources of dominance and inequality in a particular society. He presents different levels of analysis in his approach as tools that can be used to shed light on his ideas of "Us" and "Them". Van Dijk (2005, p. 730) focuses mainly on mental models as the basis on which different social practices are constructed as well as discourse and interaction. Furthermore, these mental models give the means to discourse to influence and reproduce the social representations and ideologies. Ideological systems show different social and cognitive characteristics. Hence ideology is one of the basic pillars in the formation of the identity of groups.

Wodak (2001, p. 64) explains that DHA is an approach that is proposed to deal with complexity in CDA. This approach presents a critical, multitheoretical and multimethodical research. It combines interrelated aspects to produce a complex social critique. According to Rash (2012, p. 2), within DHA the textual meanings and structures are composed of three dimensions that are the thematic level, the discursive strategies, and the linguistic forms. Such a methodology is an effective tool for analyzing self- and other- presentation strategies. Wodak et al. (2009) introduce a refined version of DHA that is supposed to be compatible with studies related to the discursive construction of national identity and the nationalist discourse.

\section{Methodology}

This section presents the model adopted to analyse the selected data. The analysis is qualitative and relies mainly on Wodak et al.'s (2009) the discursive construction of national identity approach. In this approach Wodak et al. (2009) present three levels of discourse analysis which are the thematic level, the macro-strategies level and the linguistic forms and realisations level. The first level, that is related to the thematic content works mainly on the macro-topics of a particular discourse. Within this study, the researchers will focus on the following thematic content which is the discursive construction of a shared present and future. Wodak et al. (2009, p. 3133) clarify that the construction of a common political past is based on the utilization of myths of origin, political successes in the past, times of prosperity and unity, injustice, defeats and crises. On the other hand, the construction of a shared present and future is related to topics like citizenship, political achievements, political problems in the present and future, and political crises and dangers.

As for the strategic level, the abovementioned thematic areas are carried in a set of strategies which materialize these topics related to the construction of national identities. Each one of these macrostrategies can be analytically set apart of the other strategies, but at the same time they are interrelated and may occur together. The constructive strategy refers to the ways in which the identity of a specific group is constructed by focusing on topics like solidarity, unification, and differentiation. The perpetuation strategies "attempt to maintain and reproduce a threatened national identity, i.e. to preserve, support and protect it" (Wodak et al., 2009, p. 33). Strategies of transformation work on analysing how an already established national identity can be discursively transformed into a different identity. Finally, the destructive strategies are used to dismantle specific parts of "an existing national identity construct, but usually cannot provide any new model to replace the old one" (p.33).

The third level is related to the linguistic forms and realisations. It deals with specific set of linguistic devices which function to produce the linguistic realisation of the macro-strategies. In this study, the focus will be on investigating specific lexical units that can be employed to express unity, sameness, 
uniqueness, difference and so on. The most frequent linguistic realisations, like metaphor, synecdoche, deictics, membership categorizations, evaluative lexical items are discussed within this study, as stated by Wodak et al. (2009, p. 35).

The researchers have chosen two samples from two opposing views in the UK. So, one speech by the former First Minister of Scotland Alex Salmond and one speech by the former PM of the UK David Cameron have been selected as representative texts of the Scottish and British sides within the study. Further explanation about the selected data is provided below:

One: The first case study represents a view that supports the concept of Scotland as an independent country, even though the results of the independence referendum have been already announced. The speech was presented on 19 September 2014.

Two: The second case study deals with the speech of the former PM of the UK in which he expresses his support for the Union. The speech was presented on 19 September 2014.

As for the selected data, Reisigl (2008, p. 100) states that in analysing political rhetoric, data collection is criteria-driven and based on particular points such as selecting specific political discourses in specific fields of political action, specific actors, topics, etc. In this study, the selection of data is based on a main criterion which is content because the analysis is chiefly thematic, in addition to context. So, political speeches are included if they were presented by high profile politicians in which they focus on the notion of national identity and direct their speech to a group of people. These two samples are representative because they cover the macro-topic within this study, i.e., national identity, and meet the criteria of the study.

\section{Theoretical Framework}

i.e., the discursive construction of national identity to analyse the selected data.

\section{Theoretical Framework}

Contents/ Major semantic areas

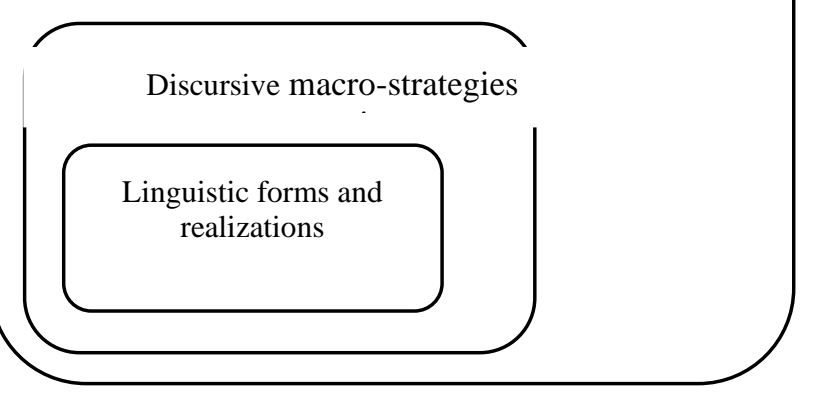

Theoretical framework of the study [adopted from Wodak et al.'s (2009)]

\section{Data Analysis}

Based on the adopted model above, the selected data include two political speeches presented by the First Minster of Scotland Alex Salmond and by the Prime Minister of the UK David Cameron. Thus, the first part analyses the speech of the Yes Scotland Campaign which was given by the First Minister of Scotland Alex Salmond, whereas the second part deals with analysing the speech of the Better Together Campaign which was introduced by the Prime Minister of the UK David Cameron.

\subsection{Analysis of the Yes Scotland Campaign Data by}

\section{Alex Salmond}

In spite of the fact that the Yes Scotland campaign failed to persuade the people of Scotland of the necessity of independence from the UK, the first 
minister of Scotland Alex Salmond keeps using the nationalist speech after the referendum as a tool. Salmond tries to create a sense of conflict between the two sides by presenting the "other" as the part that is using scaremongering strategies to hinder the independence of the Scottish people. So, he conceptualizes this conflict in "Yes campaign" and "No campaign", i.e., it is a matter of voting "Yes" for independence to be with "us", or voting "No" to be with "them". He reinforces the autonomy and independence of Scotland in such concepts. He utilises lexical items like "fought" that reinforce the idea that there is a conflict between the two campaigns. It is a perpetuation macro-strategy that aims to preserve the Scottish national identity as an already existing identity: "I am immensely proud of the campaign which Yes Scotland fought and of the 1.6 million voters who rallied to that cause by backing an independent Scotland" (BBC News, Salmond, 2014).

In this speech, Salmond focuses on presenting the UK as a political opponent that is represented mainly by parties and politicians rather than people. He overlooks the relationships between people that went on over centuries and focuses on the politicization of the UK side in this situation. He refers to the UK as "Westminster". This destructive macrostrategy aims to destroy the personal and emotional aspects of the relationship between Scotland and the UK, and shifts the attention to the political conflict. This conflict is drawn in different ways to show the UK as the "other". He uses the words of the officials in Westminster as a way of conveying a fact that both sides are fighting each other at the verbal level.

The personal pronoun "we" is used here to represent only the people of Scotland. Although the Yes votes were less than the No votes, Salmond insists on referring to the Scots as independent from the other citizens of the UK. Salmond presents metaphor of fire by associating it with a conceptualization of danger of actual fire. He uses the metaphor "fire for power" (Charteris-Black, 2017, p. 198) to express political conflict and a negative concept related to the use of fire for torturing people. Salmond mentions in his speech "to hold Westminster's feet to the fire" in order to direct the attention to the vows that were given by the PM to keep the Union. Before the independence referendum, David Cameron offered vows of more authorities to Scotland within the UK if the Scots voted to stay as a part of the UK. After losing the votes of most Scottish people, Salmond demands these vows to be fulfilled by the Westminster government. This metaphor refers to fire as a source of authority. It is used to remind people of their promises by using fire to force them to do what is legitimate. This is a perpetuation macro-strategy in which Salmond keeps mentioning Scotland and the Westminster government as two independent entities even if Scotland constitutes a part of the UK. He wants to say that there is no shared past, present or future between these two opposing sides and Scotland is an independent country even when the statistics in the referendum says the opposite. This is a unification tactic that rejects the British identity as dominant to the Scottish identity when he says that: "We now have the opportunity to hold Westminster's feet to the fire on the "vow" that they have made to devolve further meaningful power to Scotland. This places Scotland in a very strong position" (BBC News, Salmond, 2014).

One of the main strategies that are used by Salmond is portraying the insistence on the independence of Scotland as a public demand. He tries to keep political orientation away from this emotive political issue. In different occasions, Salmond avoids to mention the advantages of being a part of the UK. Moreover, he presents the government as the "other" and that the Scottish people are the "guardians" of Scotland. The use of the public demands as the basis of any political decision is the strategy of Salmond to 
legitimise whatever he says. This is a perpetuation macro-strategy that is employed to show the appropriateness of this independence referendum and its positive impact on Scotland even though most people voted against independence. Salmond does not want to lose the support of the people even those who voted "no" for independence. In addition to that, he uses metaphor of journey, i.e., "to go back into the political shadows", to direct the attention of people to the fact that the independence referendum made Scotland noticed by the Westminster government. He uses the destructive macro-strategy to portray an image of the UK as the dominant part that used to control the fate of Scottish people without giving the right for the Scottish politicians to represent their people. By using this metaphor, Salmond sees this new era after the referendum as an advantage of such a referendum that was presented by the SNP and led by Salmond regardless of the results of it as in the following speech: "The real guardians of progress are not the politicians at Westminster, or even at Holyrood, but the energised activism of tens of thousands of people who I predict will refuse meekly to go back into the political shadows" (BBC News, Salmond, 2014).

\subsection{Analysis of the Better Together Campaign Data by David Cameron}

In constructing a common present and future, the macro-strategy of perpetuation is employed by Cameron as a unification strategy that highlights subnational uniqueness of Scotland as being an influential part of the UK. The results of the referendum supported the unity of the UK. He starts his first speech after the referendum by referring to the legitimacy of the outcomes as they are the result of a democratic process. He tries to make a distinction between the people of Scotland and the politicians who are trying to affect the unity of the UK. Cameron implicitly confirms that the demand of independence referendum was a mere political matter rather than a public demand. He uses the personal pronoun "our" to refer to all the citizens of the UK.

Moreover, he stresses on the influential role that "the people of Scotland" have played to keep the unity of the UK. As a representative of the Westminster government, Cameron conceptualizes the UK as the home that has been built by the four nations within it together over the years. These four nations are referred to as members of the same family "kept our country of four nations together". In this tactic, Cameron replies indirectly to the accusations of inequality by the representatives of the Yes campaign of against the UK government: "The people of Scotland have spoken. It is a clear result. They have kept our country of four nations together. Like millions of other people, I am delighted" (BBC News, Cameron, 2014).

The theme of subnational uniqueness presents Scotland as an important part of the UK. This is an emphasis on the existence of the Scottish identity as a distinguishable entity within the UK. Cameron personifies "Scotland" as an agent that democratically chose to stay as a part of the UK. He uses the theme of shared present and future to shed light on the benefits of being one of the nations within the UK. He emphasizes the prominence of the Scottish national identification by referring to its Parliament. He uses an evaluative item "stronger" to emphasize the idea that Scotland is stronger as a part of a larger entity. After getting the majority of the No votes in the Scottish independence referendum, Cameron labels the Better Together campaign by the name that was given by the Scottish Nationalists which is "the No campaign". He wants to point out that it was a conflict between "Yes" and "No" campaigns. He excludes those who voted 
"Yes" for independence from his speech. The British

PM focuses on using the perpetuation macro-strategy in his final speech after the referendum to show the importance of staying together as one big strong country. He utilises the personal deictic "our" with the collective noun "nations" to promote unification amongst people after such a referendum that could have changed the present and future of the UK and the nations that constitute it. At the same time, he deals with the referendum as a turning point in the relationship between the UK and Scotland since it showed that there is a large number of people who disagree with the policies of the UK in relation to Scotland and the Scottish people. Cameron puts in his mind the possibility of the reoccurrence of such a referendum, so he states that there will be a change that will enhance the relations between the two sides:

Scotland voted for a stronger Scottish Parliament backed by the strength and security of the United Kingdom and I want to congratulate the No campaign for that - for showing people that our nations really are better together $[\ldots]$. We now have a chance a great opportunity - to change the way the British people are governed, and change it for the better (BBC News, Cameron, 2014).

The Prime Minister of the UK closes his speech by emphasizing that such a referendum has unified all the citizens of the UK. He uses the personal deictic "we" to express unification among people. In addition to that, he urges people to look at the changes that will happen in the future of a unified big country like the UK. As a representative of the UK as a whole, Cameron addresses those who agree and disagree with him to get together as one big nation to direct this country to the right path. He uses construction and creation metaphor in "to build that better, brighter future" as metaphor that is related to positive outcomes. The use of the attributions "better" and "brighter" to say that keeping the UK unified is the correct choice for a secured future. This is a perpetuation macro-strategy in which themes of unity and solidarity are used to maintain the Union and the existence of the British national identification with its sub-national identities: "Now we must look forward, and turn this into the moment when everyone whichever way they voted - comes together to build that better, brighter future for our entire United Kingdom" (BBC News, Cameron, 2014).

\section{Conclusions}

There are certain strategies that are used to construct, maintain or destroy national identities. In this study, the issue under investigation is related to the Scottish national identity and the British national identity and the influence of the political discourse in maintaining and reinforcing either the Scottish or the British national identification or both of them. The First Minister of Scotland, Alex Salmond, avoids themes related to the shared achievements in the present and future between the Scotland and the UK. He overlooks the personal relationships between the citizens and he presents the relationship as mere agreements between two political sides as in "to go back into the political shadows". Salmond focuses on the intranational unity between the citizens of Scotland as an independent nation even if they are still a part of the UK. On the other hand, Cameron employs the perpetuation macro-strategy to maintain the unity of the UK. He emphasizes the existence of an independent Scottish national identity that is equal to the identities of the other parts of the UK.

Conflict as a theme is used skillfully by Salmond and Cameron. The destructive macro-strategy is used to convey the conflict between the two sides. This strategy is used by Salmond in "I am immensely proud of the campaign which Yes Scotland fought..." 
مجلة لارك للفلسفة واللسانيات و العلوم الاجتماعية العدد (36) الاصدار 01- 01 -2020 (بحوث اللغة الأنكليزية)

to keep the idea of the "Other", i.e., the UK, existing in the minds of the Scots. Cameron uses the same theme to unify the people of the UK by showing those who voted "Yes" for independence as the "Other", as in "I want to congratulate the No campaign for that - for showing people that our nations really are better together". He uses personal pronouns and emotions to express his opinion. Since the Scots voted to stay within the UK, Cameron's strategy of employing the emotional aspects of the relationship between the UK and Scotland proved to be an effective tool of persuasion.

\section{References}

BBC News. (2014, September 19). Alex Salmond's statement in full. Retrieved from https://www.bbc.com/news/uk-scotlandscotland-politics-29285643

BBC News. (2014, September 19). In full: David Cameron statement on the UK's future. Retrieved from https://www.bbc.com/news/ukpolitics-29271765

Brand, J. (1978). The National Movement in Scotland. London: Routledge \& Kegan Paul.

Charteris-Black, J. (2017). Fire Metaphors Discourses of Awe and Authority. London and New York: Bloomsbury Publishing.

Esman, M. J. (1977). Perspectives on Ethnic Conflict in Industrialized Societies. In M.J. Esman (Ed.). Ethnic Conflict in the Western World. Ithaca: Cornell University Press.

Fairclough, N. (1995). Critical Discourse Analysis: The critical study of language. London: Longman.

Fowler, R., Hodge, B., Kress, G., \& Trew, T. (1979). Language \& control. London: Routledge \& Kegan Paul.

Fowler, R. (1991). Language in the News: Discourse and Ideology in the Press. London and New York: Routledge.
Glen, C. M. (2015). Nationalism, Identity and Scotland's Referendum. Contemporary European Studies. 1. 5-19.

Halbwachs, M. (1985). Das Kollektive Gedächtnis. Frankfurt am Main: Suhrkamp.

Halliday, M. A. K. (1976). A brief sketch of systemic grammar. In G. Kress (Ed.),

System and function in language London: Oxford University Press.

Ichijo, A. (2004). Scottish nationalism and the idea of Europe. London and New York: Routledge.

Jaffrelot, Ch. (2017). The Ideological Bases of Nationalism. In C. Halpern, IDENTITY (II): Individual, group, society. France: Sciences Humaines Éditions.

Meyer, M. (2001). The Discourse-Historical Approach. In R. Wodak \& M. Meyer, Methods of Critical Discourse Analysis. London: Sage Publications Ltd.

Özkirimli, U. (2010). Theories of Nationalism: A Critical Introduction (2nd Ed). New York: Palgrave Macmillan.

Rash, F. (2012). German Images of the Self and the Other: Nationalist, colonialist, and Anti-Semitic Discourse 1871-1918. UK: London. Palgrave Macmillan.

Reisigl, M. (2008). Analyzing political rhetoric. In R. Wodak and M. Krzyz anowski (eds.), Qualitative discourse analysis in the social sciences, 96-120. London: Palgrave.

Reisigl, M. \& Wodak, R. (2017). The DiscourseHistorical Approach (DHA). In J. Flowerdew \& J. E. Richardson (Eds.), The Routledge Handbook of Critical Discourse Analysis.

Sheyholislami, J. (2011). Kurdish Identity, Discourse, and New Media.USA: Palgrave Macmillan.

Skënderi, E.( 2014). We the Balkanians: A Critical Discourse Analysis of the Political Discourse. Norway: University of Bergen. 
مجلة لارك للفلسفة واللسانيات و العلوم الاجتماعية العدد (36) الاصدار 01- 01 -2020 (بحوث اللغة الأنكليزية)

Tannen, D., Schiffrin, D. \& Hamilton, H. E. (2001). In D.

Schiffrin, H. E. Hamilton \& D. Tannen (Ed.), The

Handbook of Discourse Analysis. UK: Blackwell

Publishers Ltd.

Van den Berghe, P. (1995). Does race matter? Nations and

Nationalism. 1(3),357-368.

Van Dijk, T. (1998). Ideology: A multidisciplinary Approach. London: Sage.

Van Dijk, T. (2005). Politics, Ideology and Discourse. In R. Wodak(Ed.), Elsevier Encyclopedia of

Language and Linguistics. Volume on Politics and Language 728-740.

Van Dijk, T. (2015). Critical Discourse Analysis. In D. Schiffrin, H. E. Hamilton \& D. Tannen (Ed.), The Handbook of Discourse Analysis II (2nd Ed.). UK: John Wiley \& Sons, Inc.

Wodak, R. (2001). The Discourse-Historical Approach. In R. Wodak \& M.Meyer, Methods of Critical Discourse Analysis. London: Sage Publications Ltd. Wodak, R., de Cillia, R., Reisigl, M. \& Liebhart, K. (2009), The Discursive Construction of National Identity (2nd Ed.). Edinburgh: Edinburgh University Press.

\section{Appendix 1: The Speech of First Minister of} Scotland Alex Salmond on 19 September 2014. https://www.bbc.com/news/uk-scotland-scotlandpolitics-29285643

I am immensely proud of the campaign which Yes Scotland fought and of the 1.6 million voters who rallied to that cause by backing an independent Scotland. I am also proud of the $85 \%$ turnout in the referendum and the remarkable response of all of the people of Scotland who participated in this great constitutional debate and the manner in which they conducted themselves.

We now have the opportunity to hold Westminster's feet to the fire on the 'vow' that they have made to devolve further meaningful power to Scotland. This places Scotland in a very strong position. I spoke to the prime minister today and, although he reiterated his intention to proceed as he has outlined, he would not commit to a second reading vote by 27 March on a Scotland Bill. That was a clear promise laid out by Gordon Brown during the campaign. The prime minister says such a vote would be meaningless. I suspect he cannot guarantee the support of his party. But today the point is this. The real guardians of progress are not the politicians at Westminster, or even at Holyrood, but the energised activism of tens of thousands of people who I predict will refuse meekly to go back into the political shadows.

For me right now, therefore there is a decision as to who is best placed to lead this process forward politically. I believe that in this new exciting situation, redolent with possibility, party, Parliament and country would benefit from new leadership. Therefore I have told the national secretary of the SNP that I will not accept nomination to be a candidate for leader at the annual conference in Perth on 13-15 November.

After the membership ballot I will stand down as first minister to allow the new leader to be elected by due parliamentary process. Until then I will continue to serve as first minister. After that I will continue to offer to serve as member of the Scottish Parliament for Aberdeenshire East.

It has been the privilege of my life to serve Scotland as first minister. But as I said often during the referendum campaign this is not about me or the SNP. It is much more important than that. The position is this. We lost the referendum vote but can still carry the political initiative. More importantly Scotland can still emerge as the real winner." 
Appendix 2: The Speech of the Former Prime Minister of UK David Cameron on 19 September 2014. https://www.bbc.com/news/uk-politics29271765

The people of Scotland have spoken. It is a clear result. They have kept our country of four nations together. Like millions of other people, I am delighted. As I said during the campaign, it would have broken my heart to see our United Kingdom come to an end.

And I know that sentiment was shared by people, not just across our country, but also around the world.... because of what we've achieved together in the past and what we can do together in the future. So now it is time for our United Kingdom to come together, and to move forward. A vital part of that will be a balanced settlement - fair to people in Scotland and importantly to everyone in England, Wales and Northern Ireland as well. Let us first remember why we had this debate and why it was right to do so.

The Scottish National Party was elected in Scotland in 2011 and promised a referendum on independence. We could have blocked that, we could have put it off but just as with other big issues, it was right to take - not duck - the big decision. "I am a passionate believer in our United Kingdom - I wanted more than anything for our United Kingdom to stay together.

But I am also a democrat. And it was right that we respected the SNP's majority in Holyrood and gave the Scottish people their right to have their say. Let us also remember why it was right to ask the definitive question, Yes or No. Because now the debate has been settled for a generation or as Alex Salmond has said, perhaps for a lifetime. So there can be no disputes, no re-runs - we have heard the settled will of the Scottish people.
Scotland voted for a stronger Scottish Parliament backed by the strength and security of the United Kingdom and I want to congratulate the No campaign for that - for showing people that our nations really are better together. I also want to pay tribute to Yes Scotland for a well-fought campaign and to say to all those who did vote for independence: 'we hear you'. We now have a chance - a great opportunity - to change the way the British people are governed, and change it for the better.

Political leaders on all sides of the debate now bear a heavy responsibility to come together and work constructively to advance the interests of people in Scotland, as well as those in England, Wales and Northern Ireland, for each and every citizen of our United Kingdom. To those in Scotland sceptical of the constitutional promises made, let me say this we have delivered on devolution under this Government, and we will do so again in the next Parliament. The three pro-union parties have made commitments, clear commitments, on further powers for the Scottish Parliament.

We will ensure that they are honoured in full. And I can announce today that Lord Smith of Kelvin - who so successfully led Glasgow's Commonwealth Games has agreed to oversee the process to take forward the devolution commitments with powers over tax, spending and welfare all agreed by November and draft legislation published by January. Just as the people of Scotland will have more power over their affairs, so it follows that the people of England, Wales and Northern Ireland must have a bigger say over theirs.

The rights of these voters need to be respected, preserved and enhanced as well. It is absolutely right that a new and fair settlement for Scotland should be 
accompanied by a new and fair settlement that applies to all parts of our United Kingdom. In Wales, there are proposals to give the Welsh Government and Assembly more powers. And I want Wales to be at the heart of the debate on how to make our United Kingdom work for all our nations.

In Northern Ireland, we must work to ensure that the devolved institutions function effectively. I have long believed that a crucial part missing from this national discussion is England. We have heard the voice of Scotland - and now the millions of voices of England must also be heard. The question of English votes for English laws - the so-called West Lothian question requires a decisive answer. So, just as Scotland will vote separately in the Scottish Parliament on their issues of tax, spending and welfare so too England, as well as Wales and Northern Ireland, should be able to vote on these issues and all this must take place in tandem with, and at the same pace as, the settlement for Scotland.

I hope that is going to take place on a cross-party basis. I have asked William Hague to draw up these plans. We will set up a Cabinet Committee right away and proposals will also be ready to the same timetable

I hope the Labour Party and other parties will contribute.

It is also important we have wider civic engagement about to improve governance in our United Kingdom, including how to empower our great cities. And we will say more about this in the coming days.

This referendum has been hard fought. It has stirred strong passions. It has electrified politics in Scotland, and caught the imagination of people across the whole of our United Kingdom.

It will be remembered as a powerful demonstration of the strength and vitality of our ancient democracy.

Record numbers registered to vote and record numbers cast their vote. We can all be proud of that.

It has reminded us how fortunate we are that we are able to settle these vital issues at the ballot box, peacefully and calmly.

Now we must look forward, and turn this into the moment when everyone - whichever way they voted comes together to build that better, brighter future for our entire United Kingdom." 